\title{
Discovery and Validation of a New Family of Antioxidants: The Aminopyrazine Derivatives
}

\author{
M. L. N. Dubuisson ${ }^{\natural \dagger}$, J.-F. Rees a and J. Marchand-Brynaert* bł \\ a Université catholique de Louvain, Institut des Sciences de la Vie, Unité de Biologie Animale, Bâtiment Carnoy, \\ place Croix du Sud 5, B-1348 Louvain-la-Neuve, Belgium \\ ${ }^{\mathrm{b}}$ Université catholique de Louvain, Unité de Chimie Organique et Médicinale, Bâtiment Lavoisier, place Louis \\ Pasteur 1, B-1348 Louvain-la-Neuve, Belgium
}

\begin{abstract}
Coelenteramine (2-amino-1,4-pyrazine derivative), one of the metabolites of the oxidative degradation of coelenterazine (imidazolopyrazinone derivative), is endowed with excellent antioxidative properties towards ROS/RNS, like its mother-compound. This crucial discovery, made during the study of natural bioluminescent compounds (luciferins), has stimulated the development of synthetic aminopyrazine derivatives as new leads in medicinal chemistry in the field of antioxidant-based therapies. Synthetic approaches, theoretical evaluation, radical scavenging properties in acellular and cellular tests, and in vivo evaluation are described, and illustrated with representative aminopyrazines. Tested compounds were inhibitors of lipid peroxidation and good quenchers of peroxynitrite. They efficiently protect isolated LDL against radical-induced damages. They prevent cell constituents (membranes, DNA) against injuries by various oxidative stressors (UV irradiation, hydroperoxide treatment, oxidized LDL toxicity). Lastly, aminopyrazines are remarkably active in the "hamster cheek pouch" assay (in vivo protection against ischemia-reperfusion damages).
\end{abstract}

Keywords: 2-amino-1,4-pyrazine derivatives, 2,6-diamino-1,4-pyrazine derivatives, antioxidants, radical scavengers, reactive oxygen species (ROS), reactive nitrogen species (RNS), cellular oxidative stress, ischemia-reperfusion

\section{INTRODUCTION}

Reactive oxygen species (ROS) and reactive nitrogen species (RNS), which are produced in aerobic organisms as part of normal physiological and metabolic processes, are very toxic species when present in excessive concentrations or in wrong locations. Since they can oxidise essential biological macromolecules (membrane lipids, proteins, nucleic acids,...), ROS/RNS are important mediators of cell death and tissue injury. The damages caused by oxidative stress are directly or indirectly implicated in the pathogenesis of various disease states in humans, such as cardiovascular disorders, reperfusion injury, Alzheimer's and other neurodegenerative diseases, cancer development and progression, inflammation and degenerative processes associated to ageing [1-8].

For prevention and therapeutic treatment purposes, a growing interest in the protective role of antioxidants has been expressed over recent decades. Thus, antioxidants are considered as potential drugs due to their ability to inhibit (or reduce) the cascades of free-radical reactions initiated by ROS/RNS. Most of the radical scavengers are compounds structurally related to the natural antioxidants (vitamin E, vitamin $C, \beta$-carotene, green tea extracts, flavonoids,...) and to industrial compounds such as highly hindered phenols [913].

\footnotetext{
*Address correspondence to this author at the Université catholique de Louvain, Unité de Chimie Organique et Médicinale, Bâtiment Lavoisier, place Louis Pasteur 1, B-1348 Louvain-la-Neuve, Belgium; Fax: + 33-10474168; E-mail: marchand@chim.ucl.ac.be

$\dagger_{\text {MD }}$ is a postdoctoral researcher of the FNRS (Belgium)

FJM-B is a senior research associate of the FNRS (Belgium)
}

The discovery of new leads in medicinal chemistry relies increasingly upon the research of molecular diversity, either by the construction of wide synthetic libraries, or by the isolation of natural products [14]. Since ever, the main source of naturally-occurring active molecules was our terrestrial environment (plants and animals). The systematic investigation of the marine world for the discovery of novel biologically active compounds emerged more recently, about thirty years ago [14]. In this context, bioluminescence is a fascinating phenomenon that flourishes predominantly in animals of deep ocean waters, and remains restricted to a few groups in terrestrial ecosystems [15-16]. Recently, we addressed the question of the origin and evolution of bioluminescence [17-18], i.e. the emission of ecologically functional light by living organisms, mediated by coelenterazine, one of the most important marine luciferins [19-20]. Luciferins are the natural substrates of luciferases, the enzymes that catalyse reactions emitting visible light. In all the bioluminescent organisms, light is always produced through oxidation reactions [21-22]. Thus, bioluminescence substrates are naturally designed to react with oxygen and its derived reactive species. Till now, this intrinsic property of luciferins has been well exploited in analytical biochemistry (development of various bioassays [23-26]), but not in medicinal chemistry for the discovery of new leads. This last aspect became our objective, sustained by a series of promising preliminary experiments.

Coelenterazine (2-( $p$-hydroxybenzyl)-6-( $p$-hydroxyphenyl) -8-benzyl-3,7-dihydroimi-dazolo[1,2-a]pyrazin-3-one; CLZn) has strong antioxidative properties as it is highly reactive with superoxide anion, hydroxyl radical, singlet oxygen, peroxides, lipidic radicals, nitrofurantoin-derived radicals, and peroxynitrite [17-18, 27-33]. It has been previously 
<smiles>[R]c1nc2c(Cc3ccccc3)[nH]c(-c3ccc(O)cc3)cn-2c1=O</smiles>

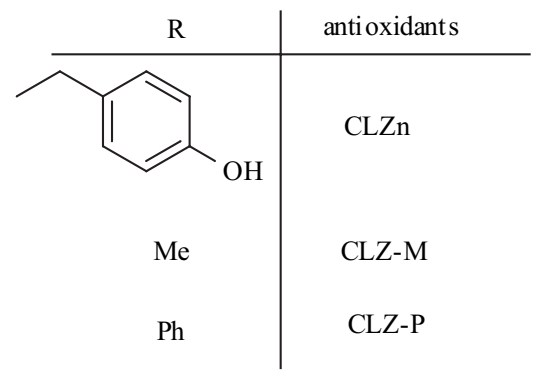<smiles>[R]C(=O)Nc1ncc(-c2ccc(O)cc2)nc1Cc1ccccc1</smiles>

CLD (luminescence CLM (antioxidant properties) properties)

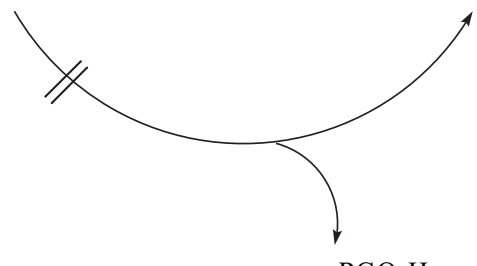

Fig. (1).

established that coelenteramide (CLD) represents a major metabolite of the oxidative degradation of CLZn, and that this compound, initially formed as an anionic species in the excited state, is responsible for the emission of light under deactivation [22, 34-36] (Fig. (1)). Using CLZn analogs, namely CLZ-M and CLZ-P (2-methyl- and 2-phenylderivatives respectively, instead of 2-p-hydroxybenzyl-), we<smiles>Nc1cnc(Br)cn1</smiles>

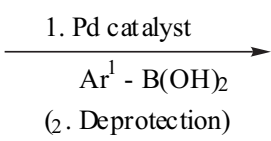<smiles>Nc1ncc(Br)nc1Br</smiles>

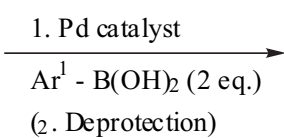<smiles>Nc1ncc([AlH2])nc1Br</smiles>

$\underset{\text { 1. Pd catalyst }}{\mathrm{Ar}^{2}-\mathrm{B}(\mathrm{OH})_{2}}$
(2. Deprotection)

cascade: CLM produced in situ prolongs the antioxidant action of its mother-compound. On the other hand, CLM derivatives (aminopyrazines) could be considered as a second generation of lead compounds, and thus developed independently of the CLZn derivatives (imidazolopyrazinones). This is the subject of the present review, another review being dedicated to CLZn analogs. (1)<smiles>Nc1cnc([AlH2])cn1</smiles>

\section{SYNTHESIS OF AMINOPYRAZINE DERIVA- TIVES}

The natural compound (CLM) has been originally prepared via a classical strategy of heterocycle formation, namely the condensation of adequately substituted $\alpha$ oximinoketone and $\alpha$-aminonitrile [39-40]. More recently, the developments of organometallic chemistry allowed the direct functionalisation of aminopyrazine precursors by Suzuki-like reactions [41]. We used this method for the

(a) Dubuisson, M. L. N. ; Marchand-Brynaert, J. ; Rees, J.-F. Antioxidative properties of new imidazolopyrazinone compounds derived from the marine luciferin coelenterazine. Current Medicinal Chemistry, in preparation. 
Table 1. List of Selected Compounds<smiles>[R][Y]1=C([R])C([R])=[X]([R])C1[R]</smiles>

\begin{tabular}{|c|c|c|c|c|c|c|}
\hline Cpd. & $\mathbf{R}^{1}$ & $\mathbf{R}^{2}$ & $\mathbf{R}^{3}$ & $\mathrm{R}^{4}$ & $\mathbf{X}$ & $\mathbf{Y}$ \\
\hline CLM & $\mathrm{Ph}-4(\mathrm{OH})$ & $\mathrm{CH}_{2} \mathrm{Ph}$ & $\mathrm{NH}_{2}$ & $\mathrm{H}$ & $\mathrm{N}$ & $\mathrm{N}$ \\
\hline 1 & $\mathrm{Ph}-4(\mathrm{OH})$ & $\mathrm{H}$ & $\mathrm{NH}_{2}$ & $\mathrm{H}$ & $\mathrm{N}$ & $\mathrm{N}$ \\
\hline 2 & $\mathrm{Ph}-3,4(\mathrm{OH})_{2}$ & $\mathrm{H}$ & $\mathrm{NH}_{2}$ & $\mathrm{H}$ & $\mathrm{N}$ & $\mathrm{N}$ \\
\hline 3 & $\mathrm{Ph}-4(\mathrm{OH})$ & $\mathrm{Ph}-4(\mathrm{OH})$ & $\mathrm{NH}_{2}$ & $\mathrm{H}$ & $\mathrm{N}$ & $\mathrm{N}$ \\
\hline 4 & $\mathrm{Ph}-4(\mathrm{OH})$ & $\mathrm{Ph}$ & $\mathrm{NH}_{2}$ & $\mathrm{H}$ & $\mathrm{N}$ & $\mathrm{N}$ \\
\hline 5 & $\mathrm{Ph}$ & $\mathrm{Ph}-4(\mathrm{OH})$ & $\mathrm{NH}_{2}$ & $\mathrm{H}$ & $\mathrm{N}$ & $\mathrm{N}$ \\
\hline 6 & $\mathrm{Ph}-3,4(\mathrm{OH})_{2}$ & $\mathrm{Ph}-4(\mathrm{OH})$ & $\mathrm{NH}_{2}$ & $\mathrm{H}$ & $\mathrm{N}$ & $\mathrm{N}$ \\
\hline 7 & $\mathrm{Ph}-4(\mathrm{OH})$ & $\mathrm{Ph}-3,4(\mathrm{OH})_{2}$ & $\mathrm{NH}_{2}$ & $\mathrm{H}$ & $\mathrm{N}$ & $\mathrm{N}$ \\
\hline 8 & $\mathrm{Ph}$ & $\mathrm{Ph}$ & $\mathrm{NH}_{2}$ & $\mathrm{NH}_{2}$ & $\mathrm{~N}$ & $\mathrm{~N}$ \\
\hline 9 & $\mathrm{Ph}-4(\mathrm{OH})$ & $\mathrm{Ph}-4(\mathrm{OH})$ & $\mathrm{NH}_{2}$ & $\mathrm{NH}_{2}$ & $\mathrm{~N}$ & $\mathrm{~N}$ \\
\hline 10 & $\mathrm{Ph}-4(\mathrm{OH})$ & $\mathrm{H}$ & $\mathrm{NH}-\mathrm{C}_{6} \mathrm{H}_{13}$ & $\mathrm{H}$ & $\mathrm{N}$ & $\mathrm{N}$ \\
\hline 11 & $\mathrm{Ph}-4(\mathrm{OH})$ & $\mathrm{H}$ & $\mathrm{NH}-\mathrm{CH}_{2} \mathrm{Ph}$ & $\mathrm{H}$ & $\mathrm{N}$ & $\mathrm{N}$ \\
\hline 12 & $\mathrm{Ph}-4(\mathrm{OH})$ & $\mathrm{Ph}-4(\mathrm{OH})$ & $\mathrm{NH}-\mathrm{C}_{6} \mathrm{H}_{13}$ & $\mathrm{H}$ & $\mathrm{N}$ & $\mathrm{N}$ \\
\hline 13 & $\mathrm{Ph}-4(\mathrm{OH})$ & $\mathrm{Ph}-4(\mathrm{OH})$ & $\mathrm{NH}-\mathrm{CH}_{2} \mathrm{Ph}$ & $\mathrm{H}$ & $\mathrm{N}$ & $\mathrm{N}$ \\
\hline 14 & $\mathrm{Ph}$ & $\mathrm{Ph}$ & $\mathrm{NH}-\mathrm{CH}(\mathrm{Me}) \mathrm{CO}_{2} \mathrm{Et}$ & $\mathrm{NH}-\mathrm{CH}(\mathrm{Me}) \mathrm{CO}_{2} \mathrm{Et}$ & $\mathrm{N}$ & $\mathrm{N}$ \\
\hline 15 & $\mathrm{Ph}-4(\mathrm{OH})$ & $\mathrm{Ph}-4(\mathrm{OH})$ & $\mathrm{NH}-\mathrm{CH}(\mathrm{Me}) \mathrm{CO}_{2} \mathrm{Et}$ & $\mathrm{NH}-\mathrm{CH}(\mathrm{Me}) \mathrm{CO}_{2} \mathrm{Et}$ & $\mathrm{N}$ & $\mathrm{N}$ \\
\hline Ref. A & $\mathrm{Ph}-4(\mathrm{OH})$ & $\mathrm{H}$ & $\mathrm{H}$ & $\mathrm{H}$ & $\mathrm{N}$ & $\mathrm{N}$ \\
\hline Ref. B & $\mathrm{Ph}-4(\mathrm{OH})$ & $\mathrm{Ph}-4(\mathrm{OH})$ & $\mathrm{H}$ & $\mathrm{H}$ & $\mathrm{N}$ & $\mathrm{N}$ \\
\hline Ref. C & $\mathrm{Ph}-4(\mathrm{OH})$ & $\mathrm{H}$ & $\mathrm{NH}_{2}$ & $\mathrm{H}$ & $\mathrm{N}$ & $\mathrm{CH}$ \\
\hline Ref. D & $\mathrm{Ph}-4(\mathrm{OH})$ & $\mathrm{H}$ & $\mathrm{NH}_{2}$ & $\mathrm{H}$ & $\mathrm{CH}$ & $\mathrm{N}$ \\
\hline Ref. E & $\mathrm{Ph}-4(\mathrm{OH})$ & $\mathrm{H}$ & $\mathrm{NH}_{2}$ & $\mathrm{H}$ & $\mathrm{CH}$ & $\mathrm{CH}$ \\
\hline
\end{tabular}

preparation of various 2-amino-1,4-pyrazines, substituted in positions C3 and/or C5 with aryl groups, in particular phenol and catechol (Fig. (2)) [37-38, 42]. These moieties were introduced as $O$-protected arylboronic acids; the methyl ethers initially used [42] were replaced with $t$ butyldimethylsilyl ethers [43], more easily deprotected.

Monosubstituted (equation (1)), symmetrically disubstituted (equation (2)) and unsymmetrically disubstituted aminopyrazines (equation (3)) were obtained:
Table 1 collects some representative compounds which chemical and biological properties are discussed in the next sections.

We also prepared 2,6-diamino-1,4-pyrazine derivatives (Fig. (3)) [44]; the precursor was obtained by substitution of 2,6-(dichloro)pyrazine with sodium azide and subsequent reduction by hydrogenation. Then, bromination and organometallic coupling of boronic acids, as before, furnished symmetrically substituted compounds (Table 1).<smiles>Clc1cncc(Cl)n1</smiles>

$\underset{\text { 1. } \mathrm{NaN}_{3}, \mathrm{DMSO}}{ }$
2. $\mathrm{H}_{2}, \mathrm{Pd} / \mathrm{C}$
3. NBS, DMSO<smiles>Nc1nc(N)c(Br)nc1Br</smiles><smiles>Nc1nc(N)c(Br)nc1Br</smiles><smiles>Nc1nc(N)c([Al])nc1[Al]</smiles>

Fig. (3). 
<smiles>Nc1ncc([AlH2])nc1[AlH2]</smiles>

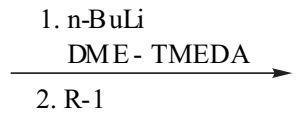

(3. Deprotection)<smiles>Nc1ncc([AlH2])nc1[AlH2]</smiles><smiles>[R]Nc1ncc([Al])nc1[AlH2]</smiles><smiles>[R]CNc1ncc([AlH2])nc1[14CH3]</smiles>

Fig. (4).

(2. Deprotection)

At last, the lipophilic character of some phenolsubstituted aminopyrazines was increased by the grafting of alkyl chains $\left(\mathrm{C}_{4}\right.$ to $\left.\mathrm{C}_{14}\right)$ on the exocyclic nitrogen. For that, two methods were exploited: (i) direct alkylation of aminopyrazinyl anion with alkyl iodides; (ii) reaction with aldehydes in the presence of phenylsilane and tin catalyst, i.e. one-step reductive amination (Fig. (4), Table 1) [43]. These reactions have to be performed on the phenol-protected precursors. In the particular case of 2,6-(diamino)pyrazine derivatives (OH-free precursors), $\mathrm{N}$-derivatization resulted from treatment with methyl glyoxal in ethanol-HCl (Fig. (5); Table 1) [44].

Some reference compounds, missing exocyclic and/or endocyclic nitrogen atoms, were also prepared by coupling arylboronic acids on the corresponding bromo (hetero)cyclic aromatic derivatives (Table 1).

\section{THEORETICAL EVALUATION}

Theoretical parameters have been recently defined to characterize antioxidants and to predict antioxidative activities. Usually these parameters are derived from the analysis of radicalar structures produced from the neutral starting materials by hydrogen $\left(\mathrm{H}^{\bullet}\right)$ or electron abstraction. Testa et al. [45-46] considered relative adiabatic oxidation potentials $\left(\Delta \mathrm{H}_{\mathrm{ox}}\right)$ and the shapes of the singly occupied molecular orbitals (SOMOs) as quantum chemical descriptors. Haemers et al. [47] correlated antioxidant activities with phenoxyl radicals stabilization energies. Recently, Li et al. [48], studying a series of phenolic compounds, found good correlations between experimental $\mathrm{K}_{\mathrm{s}}$ values (rate constants in deoxyribose degradation assay by hydroxyl radical) and several calculated parameters: $\Delta \mathrm{H}_{\mathrm{f}}$ (ArO-H bond strength), HOMO energy level (electrondonating ability), $\mathrm{E}_{\mathrm{a}}$ (enthalpy of single electron transfer) and $\mathrm{D}_{\mathrm{S}} \mathrm{r}$ (spin distribution of phenoxyl radical after $\mathrm{H}$ abstraction).

Our approach was totally different and considered the propension of aminopyrazines (and related derivatives) to present a partial biradicalar character (triplet state) more stable than the fundamental singlet state. This method is based on the investigation of Hartree-Fock wave function instabilities [49-51]. Benzene and 1,4- pyrazine presented a weak instability which was decreased and even nullified by the substitution with one or two amine functions in meta position (Table 2). But the association of aniline and 2amino-1,4-pyrazine with the para (4-hydroxy)phenyl residue significantly increased the instability; this effect was more pronounced in the pyrazine series. The addition of the phenol moiety significantly modified the equilibrium<smiles>Nc1nc(N)c([Al])nc1[Al]</smiles><smiles>CCOC(OCC)=C(C)Nc1nc(NC(C)=C(OCC)OCC)c([Al])nc1[Al]</smiles>

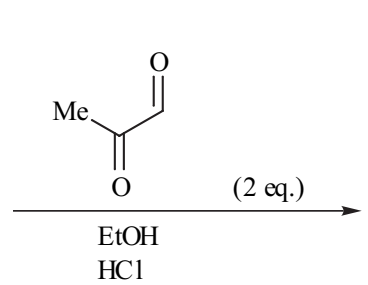

$\mathrm{H}_{3} \mathrm{O}^{+}$<smiles>CCOC(OCC)C(C)=Nc1nc(N=C(C)C(OCC)OCC)c([Al])nc1[Al]</smiles>

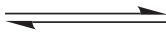<smiles>CCOC(=O)C(C)Nc1nc(NC(C)C(=O)OCC)c([Al])nc1[Al]</smiles>

Fig. (5). 
geometry and the associated electronic distribution. At last, the association of two aryl fragments with 2,6-diamino-1,4pyrazine brought the maximum of instability (Table 2). In this molecule, the amine groups are no more planar but significantly bent. The $\Delta \mathrm{E}_{\text {stable }}$ values are the energy differences between the singlet state energy and the stabilized one. These values can be seen as the abilities of the molecules to present a local biradicalar character which could be related to their intrinsic reactivity as radical scavengers. In a similar theoritical treatment (ab initio calculations using the MINI-1' basis set), we have previously demonstrated the high Hartree-Fock instabilitiy of 2,6-disubsituted imidazolopyrazinones (coelenterazine-like derivatives) [30]. Other theoretical approaches are currently under investigation, such as the calculations of the energies required to homolytically cleave the $\mathrm{O}-\mathrm{H}$ phenolic bond (formation of phenoxyl radical), and to lose one electron (formation of nitrogen radical-cation). Both processes could be operative under radicalar oxidation conditions.

Table 2. $\Delta \mathbf{E}_{\text {stable }}$ Values ${ }^{(1)}$

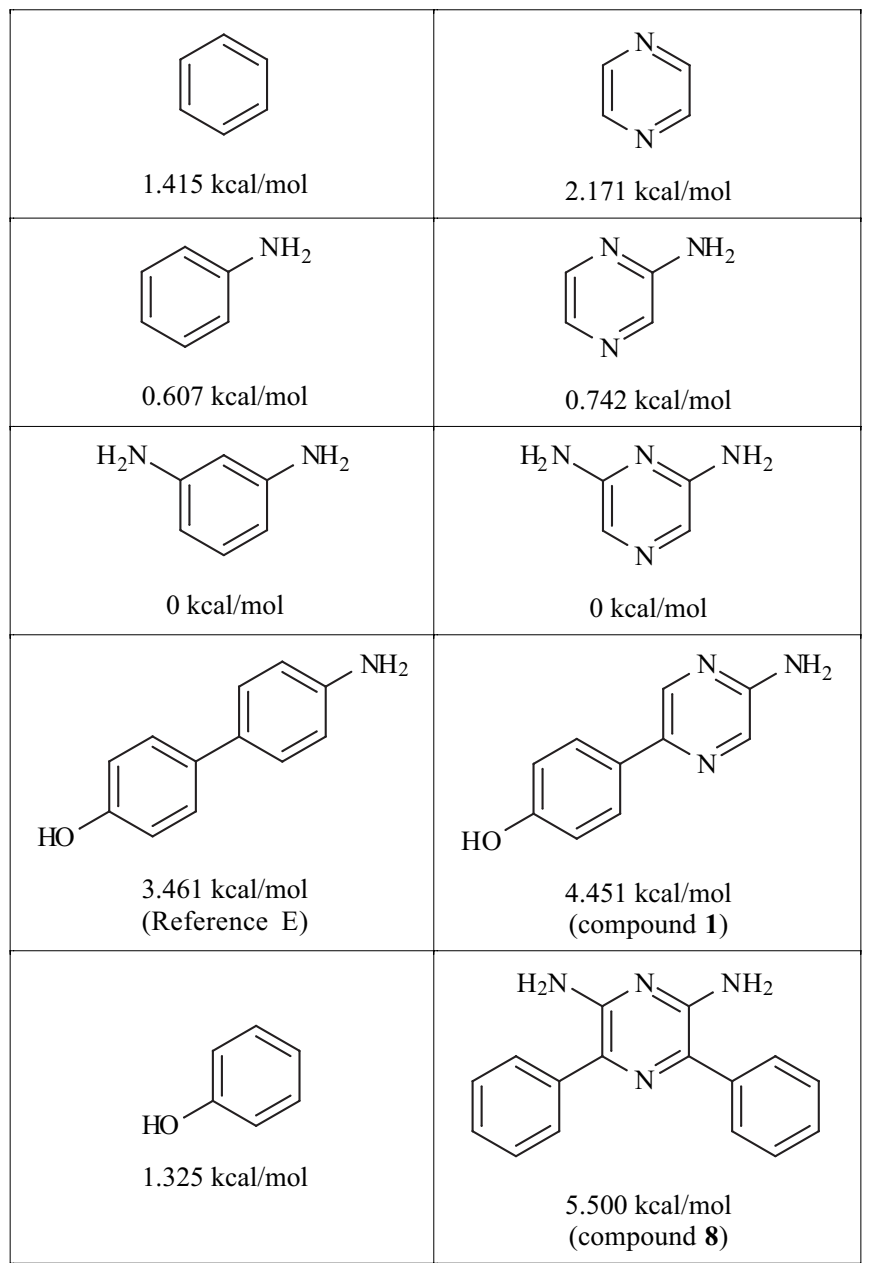

(1) All the geometry optimizations and instability calculations have been performed at the $a b$ initio level using the $6-311 \mathrm{G}^{* *}$ basis set.

\section{CHEMICAL REACTIVITY ASSAYS}

The predicted reactivity of substituted aminopyrazines towards ROS/RNS has been experimentally proved in standard chemical assays, such as the inhibition of radical- induced lipid peroxidation and the peroxynitrite quenching. This allowed to define preliminary structure-activity relationships and to propose minimal pharmacophoric structures.

\subsection{Inhibition of Lipid Peroxidation}

The pyrazine derivatives were evaluated for their ability to protect linoleic acid micelles from oxidation initiated by the water-soluble free radical initiator AAPH (2,2'-azo-bis(2amidinopropane) dihydrochloride) [52]. Micelles were obtained as follows. A solution was prepared with $100 \mu \mathrm{l}$ of $25 \%(\mathrm{v} / \mathrm{v})$ Tween 20 and $625 \mu 1$ of $50 \mathrm{mM}$ borate buffer $(\mathrm{pH}$ 9). To this $28 \mu 1$ linoleic acid were added, together with 125 $\mu \mathrm{KOH} 1 \mathrm{~N}$. The mixture was vortexed until becoming clear and the volume was adjusted to $5 \mathrm{ml}$ with borate buffer.

Addition of AAPH to the micellar solution $(0.16 \mathrm{mM}$ acid in $50 \mathrm{mM}$ phosphate buffer, $\mathrm{pH} 7.4,37^{\circ} \mathrm{C}$ and $2 \mathrm{mM}$ AAPH) caused a constant production of conjugated dienes (until reaching a plateau indicative of the full oxidation of linoleate) which was monitored every 5 minutes at $234 \mathrm{~nm}$ using a wavelength tunable microplate spectrophotometer reader. Antioxidant efficiency of the tested compounds was evaluated by the inhibition of the propagation rate (Graph (1)) calculated as follows:

$$
\text { Inhibition (\%) }=100-\frac{\mathrm{R}_{\mathrm{inh}}}{100 \mathrm{R}_{\mathrm{o}}}
$$

where $R_{i n h} / R_{0}$ is the ratio of the rate of oxidation inhibited by added compound $\left(\mathrm{R}_{\mathrm{inh}}\right)$ to that of the uninhibited oxidation $\left(\mathrm{R}_{0}=4.25 \pm 0.05\right.$ mUAbs 234 $\mathrm{nm} / \mathrm{min}$ ). Octanol/water partition coefficients $(\log \mathrm{P})$ were determined by the shake-flask method.

A first set of results is presented in Table 3 [38]. At 5 $\mu \mathrm{M}$ concentration, CLM induced $61 \%$ of inhibition. Suppression of the 3-benzylsubstituent, to give the less lipophilic aminopyrazine 1 , significantly reduced the

Table 3. Inhibition of AAPH-Induced Lipid Peroxidation by Pyrazine Derivatives at $5 \mu \mathrm{M}$

\begin{tabular}{|c|c|c|}
\hline Cpd $^{(\mathbf{1})}$ & \% inhibition $^{(\mathbf{2})}$ & Log $_{\text {octanol/water }}{ }^{(3)}$ \\
\hline \hline CLM & $61.50 \pm 1.11 * * *$ & $1.09 \pm 0.03$ \\
\hline $\mathbf{1}$ & $17.02 \pm 1.64 * * *$ & $0.13 \pm 0.01$ \\
\hline $\mathbf{3}$ & $65.62 \pm 1.06 * * *$ & $1.95 \pm 0.09$ \\
\hline $\mathbf{4}$ & $65.50 \pm 1.30^{* * *}$ & $1.85 \pm 0.06$ \\
\hline $\mathbf{5}$ & $33.40 \pm 0.40^{* * *}$ & $>2$ \\
\hline $\mathbf{1 1}$ & $71.51 \pm 1.54 * * *$ & $>2$ \\
\hline $\mathbf{1 3}$ & $81.36 \pm 0.56 * * *$ & $>2$ \\
\hline Ref. $\mathbf{A}$ & $7.32 \pm 1.36 * *$ & $1.25 \pm 0.32$ \\
\hline Ref. B & $38.83 \pm 1.65 * * *$ & $>2$ \\
\hline
\end{tabular}

(1) See structures in Table

(2) Values represent means \pm sem. of triplicate experiments; statistical comparison with controls (AAPH only): ** $\mathrm{p}<0.01 ; * * * \mathrm{p}<0.001$

(3) Values ( \pm sem) measured in triplicates; shake-flask method 


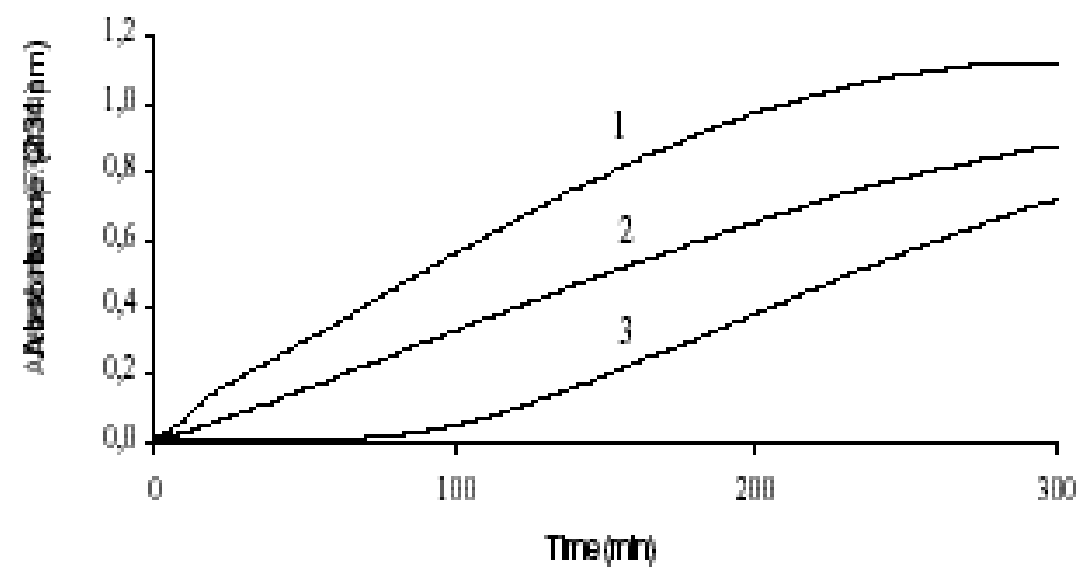

Graph 1. Typical profiles of AAPH-induced linoleate peroxidation in the presence or absence of AMP antioxidants. Lipid peroxidation is measured through the formation of conjugated dienes measured by absorbance at $234 \mathrm{~nm}$. Curve 1 is the profile obtained with the control sample treated with AAPH only. Curve 2 shows a decrease in the propagation rate (slope) of the lipid peroxidation reaction after the use of an AMP like CLM or compound 3. Curve 3 combines a lag time and a decrease in the rate of propagation and is observed with bisamine or catecholic AMP compounds.

activity. Disubsituted aminopyrazines 3 and 4 are equally active as the natural CLM. But disubstituted aminopyrazine 5 appeared less active; this suggests that the para regiochemistry for the amino and phenolic substituents on the 1,4-pyrazine nucleus, corresponding to the most extended conjugation, is required. Increasing lipophilicity of 1 by $N$-alkylation, restored a good activity, as illustrated with compounds 11 and 13. Compounds devoid of the amino function (Ref.A and Ref.B) partially lost their good activity. The $O$-protected precursors (compounds in which the hydroxyl group was replaced with a methoxy group) were also tested and found to be totally inactive (results not shown); thus, the antioxidant power of CLM and related aminopyrazines resides in their ability to form highly stabilized phenoxyl radical (Fig. (6)).

In a second set of experiments (Table 4) the previous results were confirmed: the inhibition activity is linked to a minimal structural motif, i.e. 2-amino-5- $p$-hydroxyphenyl1,4-pyrazine, and to a high lipophilic character provided by substituents in positions $\mathrm{C} 3$ and/or NH. At concentration of $2.5 \mu \mathrm{M}$, the inhibition of the propagation rate caused by compounds 10 and 12 was more than $90 \%$.
We further evaluated the effect of two structural modifications susceptible to improve the antioxidant activity of aminopyrazines, namely the introduction of a catechol function (second hydroxyl group) and the addition of a second amine substituent [38]. These series of compounds showed a different profile of inhibition comparatively to CLM: they delayed the onset of AAPH-induced lipid peroxidation (Graph (1)); after this latency period (lag phase) the oxidation proceeded at a slower or similar rate as that in the absence of antioxidant (control). Thus, the catechol derivatives 2, 6 and 7 (Table 4), tested at $2.5 \mu \mathrm{M}$, induced a lag phase of 250-270 min. The diamine-diphenol derivative 9 was similarly active [44]. Interestingly, the diamine compound 8 devoid of phenol motif was also able to delay the onset of lipid peroxidation, with the same activity as Trolox, a water-soluble analog of vitamin E (lag phase of 100-110 min). Lower concentrations of all these compounds induced shorter latency periods. Therefore, the 2,6-diamino1,4-pyrazine nucleus with extended conjugation exhibits an antioxidant activity, different from that of phenolic derivatives, and so constitutes an additional pharmacophoric structure, as predicted by our theoretical evaluation (see row<smiles></smiles><smiles>[R]C1=NC(=C2C=CC(=O)C=C2)C=NC1=[V]</smiles><smiles>CCC</smiles><smiles>[R]C1=NC(=C2C=CC(=O)C=C2)C=NC1N</smiles>

Fig. (6). 
Table 4. Inhibition of AAPH-Induced Lipid Peroxidation by Aminopyrazine Derivatives at $2.5 \mu \mathrm{M}$

\begin{tabular}{|c|c|c|c|}
\hline Cpd $^{(1)}$ & $\%$ inhibition $^{(2)}$ & latency period (min) & Log $P_{\text {octanol/water }}$ \\
\hline CLM & $39.26 \pm 0.31 * * *$ & I & $1.09 \pm 0.03$ \\
\hline 10 & $93.10 \pm 7.30 * * *$ & I & $>2$ \\
\hline 11 & $59.94 \pm 3.57 * * *$ & / & $>2$ \\
\hline 12 & $96.60 \pm 9.50 * * *$ & / & $>2$ \\
\hline 13 & $78.65 \pm 2.24 * * *$ & I & $>2$ \\
\hline 2 & $22.90 \pm 5.80 *$ & $270.50 \pm 3.13$ & $0.94 \pm 0.16$ \\
\hline 6 & $10.37 \pm 2.10$ & $257.35 \pm 2.20$ & n.d. \\
\hline 7 & $33.99 \pm 5.35 * * *$ & $250.55 \pm 6.49$ & $1.10 \pm 0.04$ \\
\hline 8 & $0.01 \pm 2.50$ & $112.35 \pm 1.74$ & n. d. \\
\hline 9 & $26.27 \pm 2.77 *$ & $255.08 \pm 16.29$ & $1.47 \pm 0.03$ \\
\hline Vitamin E & $0.59 \pm 1.34$ & $170.99 \pm 17.34$ & $1.09 \pm 0.03$ \\
\hline Trolox & $0.46 \pm 3.26$ & $102.01 \pm 0.35$ & n.d. \\
\hline EGCG & $6.57 \pm 1.97$ & $214.66 \pm 7.61$ & n.d. \\
\hline
\end{tabular}

(1), (2), and (3): see Table 3; n.d. $=$ not determined; *, $\mathrm{p}<0.05 ;{ }^{* * *}, \mathrm{p}<0.001$

3 , Table 2). In this case, the possibility of forming a stabilized radical-cation could be the determining factor (Fig. (7)). The occurrence of a latency period with compounds 2 ,

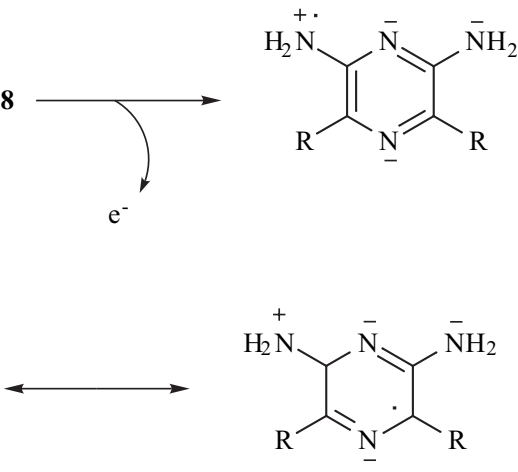

Fig. (7).

$6,7,8$ and 9 suggests that a more efficient stabilization of the radical intermediate is achieved, this intermediate being unable to further react with the lipid targets [38].

Our first chemical evaluation of aminopyrazine derivatives clearly showed the high potential of these molecules as radical scavengers $(\mathrm{R} \cdot \mathrm{ROO}, \mathrm{RO} \cdot \ldots)$; they were more active than classical references such as vitamin $\mathrm{E}$ and the polyphenolic compound epigallocatechin gallate (EGCG) extracted from green tea leaves (Table 4).

\subsection{Reactivity towards Peroxynitrite}

A solution of pure peroxynitrite was prepared according to Koppenol et al. [53]. The reactivity assay was based on the oxidation of dihydrorhodamine-123 (DHR) induced by peroxynitrite into fluorescent rhodamine-123 (Rh) which production was followed at $515 \mathrm{~nm}$ (excitation wavelength) and $555 \mathrm{~nm}$ (emission wavelength). In the presence of tested compounds, quenching of peroxynitrite provoked a decrease of fluorescence; inhibition (\%) was calculated as follows:

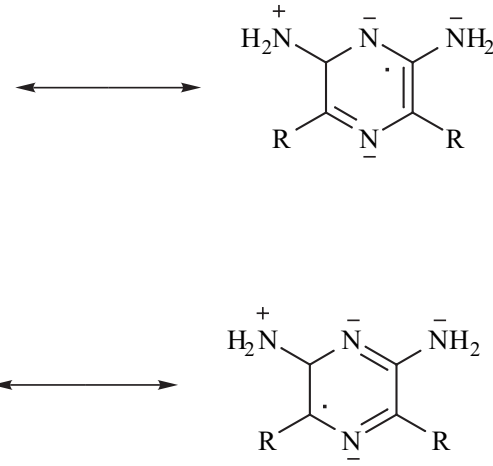

where $A_{\text {inh }}$ is the signal generated in the presence of the inhibitor (at $2.5 \mu \mathrm{M}$ ) and $A_{O}$ is the signal observed in the absence of inhibitor. By varying the inhibitor concentration from $0.25 \mu \mathrm{M}$ to $2.5 \mu \mathrm{M}$, a $\mathrm{IC}_{50}$ value was determined. This corresponds to the antioxidant concentration giving a $50 \%$ inhibition of DHR oxidation by peroxynitrite. Results are collected in Table 5 (2): the smallest values of $\mathrm{IC}_{50}$ correspond to the most active compounds as radical scavengers. Aminopyrazines 1, 3 and 4 (phenol derivatives) were more efficient than the natural CLM. But phenol derivative 5 possessing the amine and phenol substituents in

(2) Burton, M.; Marchand, C.; Janssens, B.; Marchand-Brynaert, J.; Rees, J.-F Unpublished results. 
Table 5. Quenching of Peroxynitrite by Aminopyrazine Derivatives and Reference Compounds

\begin{tabular}{|c|c|}
\hline $\mathrm{Cpd}^{(1)}$ & $\mathrm{IC}_{50}(\mu \mathrm{M})$ \\
\hline CLM & $0.92 \pm 0.02^{\mathrm{a}, \mathrm{e}}$ \\
\hline 1 & $0.74 \pm 0.03$ a, f \\
\hline 3 & $0.52 \pm 0.02^{b}$ \\
\hline 4 & $0.50 \pm 0.06^{b}$ \\
\hline 5 & $1.42 \pm 0.02 \mathrm{c}, \mathrm{d}$ \\
\hline 11 & $0.95 \pm 0.05^{\mathrm{a}}$ \\
\hline 13 & $1.68 \pm 0.05^{\mathrm{c}, \mathrm{h}}$ \\
\hline 2 & $0.53 \pm 0.01^{b}$ \\
\hline 6 & $0.47 \pm 0.01^{b}$ \\
\hline 7 & $0.59 \pm 0.03 \mathrm{~b}$ \\
\hline 8 & $1.13 \pm 0.10^{\mathrm{d}, \mathrm{e}}$ \\
\hline 9 & $0.29 \pm 0.01^{b}$ \\
\hline 15 & $1.05 \pm 0.01 \mathrm{e}, \mathrm{f}$ \\
\hline Ref. A & $4.91 \pm 0.18^{\mathrm{g}}$ \\
\hline Ref. B & $1.75 \pm 0.09^{h}$ \\
\hline Ref. C & $1.14 \pm 0.02^{\mathrm{d}}$ \\
\hline Ref. D & $0.48 \pm 0.02^{b}$ \\
\hline $\begin{array}{l}\text { Ref. E } \\
\text { Ebselen } \\
\text { EGCG } \\
\text { Trolox }\end{array}$ & $\begin{array}{c}0.57 \pm 0.02^{\mathrm{b}} \\
0.94 \pm 0.09^{\mathrm{a}, \mathrm{c}} \\
0.35 \pm 0.03 \mathrm{~b} \\
0.47 \pm 0.01 \mathrm{~b}\end{array}$ \\
\hline
\end{tabular}

(1) see structures in Table 1

(2) values represent means \pm sem of triplicate experiments. Data sharing the same letter are not significantly different

the relative ortho position on the pyrazine nucleus (instead of the para position) was less active: this confirms the previously established minimal pharmacophoric structure. Increasing lipophilicity did not provide a beneficial effect in this test (see CLM and compounds 11 and 13), because incorporation into micelles was not implicated in this case like in the lipid peroxidation test.

As before, amongst the most active compounds we found those possessing a catechol motif (compounds 2, 6 and 7) and a supplementary unsubstituted amine function in position C6: diaminopyrazine 9 was remarkably potent. Here again, for all tested compounds, masking the hydroxyl function by methylation (protected phenolic derivatives), dramatically reduced their antioxidant power (results not shown). The relative importance of the exocyclic and endocyclic nitrogen atoms has been pointed out by the results obtained with the reference compounds $\mathrm{A}$ to $\mathrm{E}$ : interestingly, only one exocyclic amine function appears essential for chemical reactivity.

\subsection{Miscellaneous}

In contrast to imidazolopyrazinones which reacted very rapidly with superoxide anion (CLZn, Fig. (1): $\mathrm{k}=1.2 \pm$ $\left.0.2 \times 10^{5} \mathrm{M}^{-1} \mathrm{~S}^{-1}[28,30]\right)$, aminopyrazines were poorly reactive $\left(9: \mathrm{k}=1.9 \pm 0.1 \times 10^{3} \mathrm{M}^{-1} \mathrm{~s}^{-1} ; 14: 4.9 \pm 0.11 \mathrm{x}\right.$ $\left.10^{3} \mathrm{M}^{-1} \mathrm{~s}^{-1} ; 15: 2.6 \pm 0.1 \times 10^{3} \mathrm{M}^{-1} \mathrm{~s}^{-1}\right)$ or totally unreactive (no reaction for CLM, 1, 3, 4, 5, 8, 10, 11; catechol derivatives 2, 6, 7 were not determined). Here again, 2,6diamino-1,4-pyrazines behaved differently from 2-amino-1,4pyrazines.

CLM (Fig. 1) showed a high reactivity towards singlet oxygen $\left(\mathrm{k}=5.2 \pm 0.6 \times 10^{7} \mathrm{M}^{-1} \mathrm{~s}^{-1}[27,33]\right)$. The other aminopyrazines were not tested.

The catechol derivatives 2, 6 and $7(100 \mu \mathrm{M})$ were found to be good ligands of iron: they displaced ferrozine from its ferrozine-Fe ${ }^{++}$complex $(100 \mu \mathrm{M} ; \mathrm{pH} 6.9 ; \lambda \max =562 \mathrm{~nm})$ with an efficiency of $65 \%, 52 \%$ and $46 \%$ respectively, compared to DFO (desferrioxamine) considered as the reference $(100 \%$ of efficiency). This property is most probably linked to the presence of a catechol motif in the structures 2, 6 and 7, since other aminopyrazines like 3 do not interfere with the ferrozine-Fe ${ }^{++}$complex. From the literature, it appears that the pyrazine motif could be a modest iron ligand $[54,55,56]$, but no information is available about aminopyrazine. Whatever it may be, the combination of antioxidant capacity with iron chelator property could provide an original dual activity, particularly interesting in the search for new neuroprotective agents [57] (see paragraph 6.3).

\section{LDL PROTECTION}

In this section, we next considered the ability of (di)aminopyrazines to protect human low density lipoproteins (LDL) against injuries caused by ROS/RNS. LDL oxidation plays a major role in the development of atherosclerosis since oxidized-LDLs accumulate faster in arteries. Thus, molecules able to protect LDLs (similarly to vitamin $\mathrm{E}$ and probucol) are potentially of therapeutic interest.

Human LDLs were prepared using a modified method from Chung et al. [58]. Briefly, normal ABO human serum was pooled and centrifuged (50000 rpm) during $16 \mathrm{~h}$ at $10^{\circ} \mathrm{C}$ in a Beckman L8-80 centrifuge with a Beckman Vti 50 vertical rotor. The top fraction was collected and the density adjusted to $1.27 \mathrm{~g} / \mathrm{ml}$ with $0.54 \mathrm{~g} / \mathrm{ml}$ solid $\mathrm{KBr}$. The solution was distributed in two centrifugation tubes under $30 \mathrm{ml}$ of $0.89 \%(\mathrm{w} / \mathrm{v}) \mathrm{NaCl}$ solution before being ultracentrifuged again for $3 \mathrm{~h}$. At the end of the centrifugation, 3 fractions of lipoproteins appear separated corresponding to the very low-density lipoproteins (VLDL), low-density lipoproteins (LDL) and high-density lipoproteins (HDL). The middle fraction was collected and dialyzed against $10 \mathrm{mM}$ Tris/ $0.15 \mathrm{M} \mathrm{NaCl}$ buffer adjusted to $\mathrm{pH} 7.2$ and containing $0.1 \mathrm{~g} / \mathrm{l}$ EDTA for 72 hours. After a second dialysis against a phosphate EDTA-free buffer, LDL was filtered on a Millipore $0.22 \mu \mathrm{M}$ filter and collected in a sterile tube. They were stored at $4^{\circ} \mathrm{C}$ in the dark before use.

The oxidation of LDLs $(100 \mu \mathrm{g} / \mathrm{ml})$ was induced by addition of $\mathrm{CuSO}_{4}(10 \mu \mathrm{M})$ and monitored by the appearance of malondialdehyde (MDA), one of the final products resulting from the peroxidation of polyunsaturated fatty acids. A chromogenic derivative (detected by fluorescence: excitation wavelength $515 \mathrm{~nm}$ and emission 
wavelength $555 \mathrm{~nm}$ ) was formed by reaction with thiobarbituric acid (TBA) [59].

Results collected in Table 6 are expressed as $t_{1 / 2}$, i.e. the time required for oxidation of $50 \%$ LDLs. Here again, compound 1 exemplified the minimal structural features for antioxidant activity, and enhanced lipophilicity improved the activity (CLM, 3, 4, 11 and 13). Catechol (2, 6 and 7) and diamine derivatives (9) were similarly active, and comparable to trolox and probucol. For all compounds, methylation of the phenolic groups totally suppressed the antioxidant capacity (results not shown). We have to notify that the catechol derivatives $(2,6$, and 7$)$ are able to complex $\mathrm{Cu}^{++}$and, therefore, prevent the oxidation of LDLs through this mechanism.

Table 6. Time Required for $50 \%$ LDL Oxidation $\left(t_{1 / 2}\right)$ in the Presence of Aminopyrazine Derivatives at $1.25 \mu \mathrm{M}$

\begin{tabular}{|c|c|}
\hline Cpd $^{(\mathbf{1})}$ & $\mathbf{t}_{\mathbf{1 / 2}}{ }^{(\mathbf{2})(\mathbf{3})}$ \\
\hline \hline CLM & $241.23( \pm 1.87)$ \\
\hline $\mathbf{1}$ & $126.49( \pm 0.64)$ \\
\hline $\mathbf{3}$ & $204.56( \pm 3.24)$ \\
\hline $\mathbf{4}$ & $228.44( \pm 2.39)$ \\
\hline $\mathbf{2}$ & $177.16( \pm 1.91)$ \\
\hline $\mathbf{6}$ & $211.56( \pm 1.87)$ \\
\hline $\mathbf{7}$ & $200.05( \pm 3.74)$ \\
\hline $\mathbf{9}$ & $191.69( \pm 1.37)$ \\
\hline $\mathbf{1 1}$ & $249.76( \pm 3.95)$ \\
\hline $\mathbf{1 3}$ & $286.50( \pm 1.93)$ \\
\hline Probucol & $206.79( \pm 3.01)$ \\
\hline Trolox & $148.57( \pm 1.04)$ \\
\hline
\end{tabular}

(1) see Table 1

(2) values are the means \pm sem of 9 measurements

(3) in the absence of inhibitor ( $\mathrm{LDL}+\mathrm{Cu}), \mathrm{t}_{1 / 2}=101.87( \pm 0.37) \mathrm{min}$. All the tested compounds are significantly different from the control in the absence of inhibitor $(\mathrm{p}<0.001)$

In another test, LDL $(0.125 \mathrm{mg} / \mathrm{ml})$ oxidation was initiated by peroxynitrite $(100 \mu \mathrm{M})$. Peroxynitrite is a strong oxidant that can be formed in the vessel wall. It mediates LDL oxidation, which is relevant with the development of the early steps as well as progression of atherosclerosis $[60,61,62]$.

The presence of oxidized LDLs was determined by electrophoresis on agarose gel: more LDLs are oxidized, the farest they migrate on the gel (measurement of the increase of migration distance). In the presence of an inhibitor (100 $\mu \mathrm{M})$, the migration distance was reduced. Results of Table 7 are expressed as percentages of distance reduction compared to totally oxidized LDLs; thus high values correspond to efficient compounds $(100 \%=$ native LDLs and $0 \%=$ totally oxidized LDLs).

All tested molecules protected LDLs against peroxynitrite-initiated oxidation; no particular structureactivity relationship could be inferred.
Table 7. Inhibition of LDL Oxidation Initiated by Peroxynitrite

\begin{tabular}{|c|c|}
\hline Cpd $^{(\mathbf{1})}$ & Distance reduction $^{(\mathbf{2})}(\mathbf{\%})$ \\
\hline \hline CLM & 59 \\
\hline $\mathbf{1}$ & 92 \\
\hline $\mathbf{3}$ & 69 \\
\hline $\mathbf{4}$ & 78 \\
\hline $\mathbf{5}$ & 50 \\
\hline $\mathbf{6}$ & 59 \\
\hline $\mathbf{7}$ & 46 \\
\hline $\mathbf{8}$ & 83 \\
\hline $\mathbf{9}$ & 75 \\
\hline $\mathbf{1 1}$ & 50 \\
\hline
\end{tabular}

(1) see structures in Table 1

(2) After $5 \mathrm{~min}$ of diffusion, sample electrophoresis was performed for $30 \mathrm{~min}$ at 100 Volts.

\section{CELLULAR TESTS}

Following the positive preliminary results collected from the assays on isolated biomolecules, we were encouraged to evaluate our compounds in representative cellular tests. Possible cell toxicity was first assayed on cultured rat hepatocytes. Then, protection of keratinocytes (constitutive cells of epidermis), against UV irradiation was considered. Lastly, protection of neuronal cells and endothelial cells against oxidative stress, $\mathrm{H}_{2} \mathrm{O}_{2}$-induced and oxidized LDLinduced respectively, has been studied. All the selected cellular models are representative of pathological conditions.

\subsection{Toxicity on Hepatocytes}

The survival of rat hepatocytes cultured in the presence of tested compounds has been measured with the MTT assay, as previously described [29]. This test determines the mitochondrial succinate dehydrogenase activity that is proportional to cell survival. Metabolically active cells enzymatically transform 3-(4,5-dimethylthiazol-2-yl)-2,5diphenyltetrazolium bromide (MTT) into formazan which is detected at $540 \mathrm{~nm}$. In the presence of a toxic compound, the number of cells able to produce formazan decreases.

Toxicity of CLM and representative aminopyrazines 1, 2, $3,7,11,13$ and 15, has been evaluated at 25, 50, 75 and $100 \mu \mathrm{M}$ concentrations. Compounds $13(100 \%$ mortality at $50 \mu \mathrm{M})$ and $15(50 \%$ mortality at $100 \mu \mathrm{M})$ were toxic for hepatocytes but not CLM and other synthetic analogs. CLM was found to be excreted (>90\%) by hepatocytes as sulfoand glucoronoconjugates.

\subsection{Keratinocyte Protection Against UVB and UVA- Irradiation Damages}

The protective effect of aminopyrazines has been evaluated on human keratinocytes (HaCaT) submitted to UVB irradiation $(312 \mathrm{~nm})$ [42]. Cellular death was determined by measuring the amount of lactate 


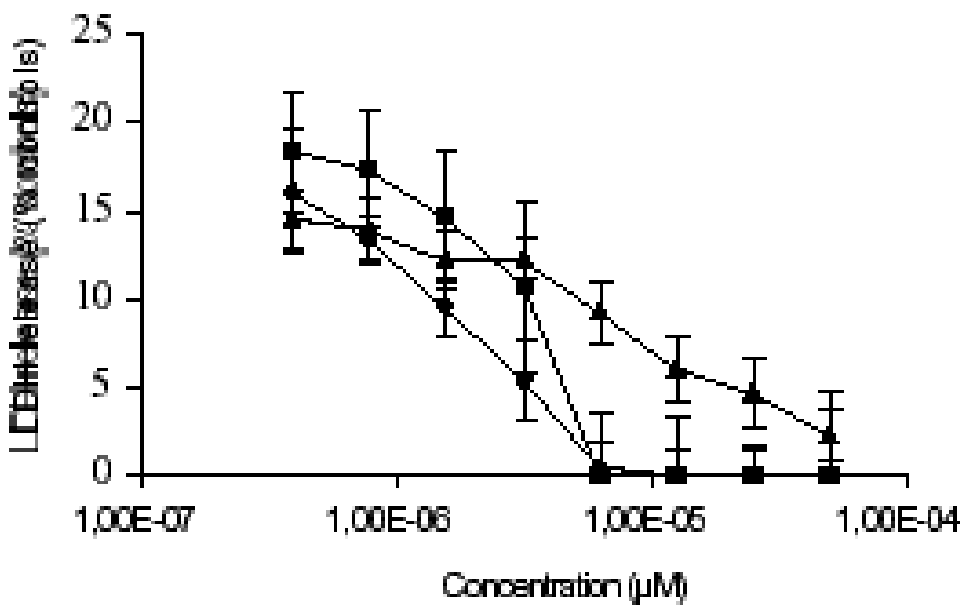

Graph 2. Protection of keratinocytes by tested compounds against UVB-induced cytotoxicity. Cells were treated by $200 \mathrm{~mJ} / \mathrm{cm}^{2} \mathrm{UVB}$ in the absence or presence of increasing concentrations of antioxidants $(\bullet$, cpd $7 ; \boldsymbol{\Delta}$, cpd 3; $\mathbf{\square}$, green tea extract: EGCG/ECG). Viability was measured as a function of LDH release (mean \pm sem of 3 replicates).

dehydrogenase $(\mathrm{LDH})$ released into the cell culture supernatant. LDH is a cytosolic enzyme liberated when cells are injured; the LDH assay constitutes an indirect measurement of damages occurring at the cytoplasmic membrane.

Cells were incubated with the tested compound $(50 \mu \mathrm{M}$ in PBS) for $30 \mathrm{~min}$ at $37^{\circ} \mathrm{C}$, then irradiated with UVB (200 $\mathrm{mJ} / \mathrm{cm}^{2}$ ) for $3 \mathrm{~min}$. After that, cells were incubated in the culture medium containing the tested compound for $24 \mathrm{~h}$ at $37^{\circ} \mathrm{C}$. LDH release was then measured; results were expressed as percentages of LDH in the supernatant with respect to the total amount of LDH associated with cells (non-irradiated and non treated). CLM and aminopyrazines $1,2,3,4,5,6$ and 7 brought a total protection against UVB-induced damages $(\sim 0 \% \mathrm{LDH}$ release, at $50 \mu \mathrm{M})$. Diaminopyrazines $8,9,14$ and 15 were similarly efficient $(\sim 0 \% \mathrm{LDH}$ release, at $50 \mu \mathrm{M})$. Two representative compounds, 3 (phenolic derivative) and 7 (catechol derivative), were compared to a green tea extract containing mainly epigallocatechin gallate (EGCG) and epicatechin gallate (ECG). All compounds prevented LDH-release in a dose-dependent manner; at lower concentrations, catechol derivative 7 was the most efficient (Graph (2)) [42]. No filter effect seemed to be involved in the observed protection: tests carried out with CLM and compound 3 indicated that protection was suppressed when the antioxidant was applied solely during the irradiation; also, similar protections were measured when cells were preincubated with the antioxidant, irradiated in antioxidant-free saline and placed back into PBS containing the aminopyrazines. Extinction coefficients at $312 \mathrm{~nm}$ were similar for mono- (e.g. $3,5960 \mathrm{M}^{-1} \mathrm{~cm}^{-1}$ ) and diaminopyrazines (e.g. 8, $4880 \mathrm{M}^{-1} \mathrm{~cm}^{-1}$ ).

UVA irradiation (320-380 nm) is also responsible for cell injury via photoactivated reactions leading to the intracellular production of ROS. UVA-induced damages on keratinocyte DNA could be visualized with the "comet" assay (Single Cell Gel Electrophoresis) measuring the amount of DNA fragmentation [63]: cell irradiation with 2.5 $\mathrm{J} / \mathrm{cm}^{2}$ and $5 \mathrm{~J} / \mathrm{cm}^{2}$ UVA (365nm) caused respectively $25 \%$ and $40 \%$ of nuclear DNA fragmentation.
Keratinocytes were incubated with $50 \mu \mathrm{M}$ aminopyrazines 3 and 7 for $30 \mathrm{~min}$ at $37^{\circ} \mathrm{C}$ in PBS buffer, then UVA -irradiated $\left(5 \mathrm{~J} / \mathrm{cm}^{2}\right)$. The "comet" assay was run immediately as to prevent DNA-repair mechanisms to operate. The protection brought by 7 was total while no protection was observed with compound 3 . The protection by 7 could not be ascribed to a filter effect as compound 3 absorbs UVA more strongly. (3)

\subsection{Neuronal Cell Protection Against Oxidative Stress}

The rat pheochromocytoma line $\mathrm{PC} 12$ cells provide a useful model system for the investigation of neuronal injury [64], especially with the use of peroxides [65].

PC12 cells were treated with hydrogen peroxide for 30 min at $37^{\circ} \mathrm{C}$, then cultured in fresh medium during $24 \mathrm{~h}$. Cell mortality was measured by the MTT test (see paragraph 6.1). The protective effect of compound 7 (catechol derivative) at 25,50 and $100 \mu \mathrm{M}$ has been evaluated on cells stressed with $125 \mu \mathrm{M} \mathrm{H}_{2} \mathrm{O}_{2}$ (Graph (3): MTT assay). In the absence of 7, cell survival decreased in the presence of $\mathrm{H}_{2} \mathrm{O}_{2}$. Trolox (water-soluble analogue of vitamin E) used at concentrations of 25 to $100 \mu \mathrm{M}$ was unable to protect cells, while 7 revealed to be highly efficient. At $250 \mu \mathrm{M} \mathrm{H}_{2} \mathrm{O}_{2}$, cell survival was still superior to $70 \%$, in the presence of 7 at $100 \mu \mathrm{M}$ (results not shown).

Other aminopyrazines were tested, as shown in Table 8: only the catechol derivatives $(2,6,7)$ efficiently protected PC12 cells against oxidative stress induced by $250 \mu \mathrm{M}$ $\mathrm{H}_{2} \mathrm{O}_{2}$. Phenol derivatives were inactive $(1,3)$ or very poorly active (CLM, 11). This result indicated the crucial role of the catechol motif for neuroprotective action. Indeed, 1,2dihydroxybenzene (catechol) was moderately active, suggesting a possible metal-complexing effect. However, in our test, DFO and deferiprone (reference metal-ligands) were less active than compound 7 (Table 8). Thus, whatever its mechanism of action may be, aminopyrazine 7 is endowed with remarkable neuroprotective activity.

${ }^{3}$ ) Le Gall, R.; Rees, J.-F., Unpublished results. 


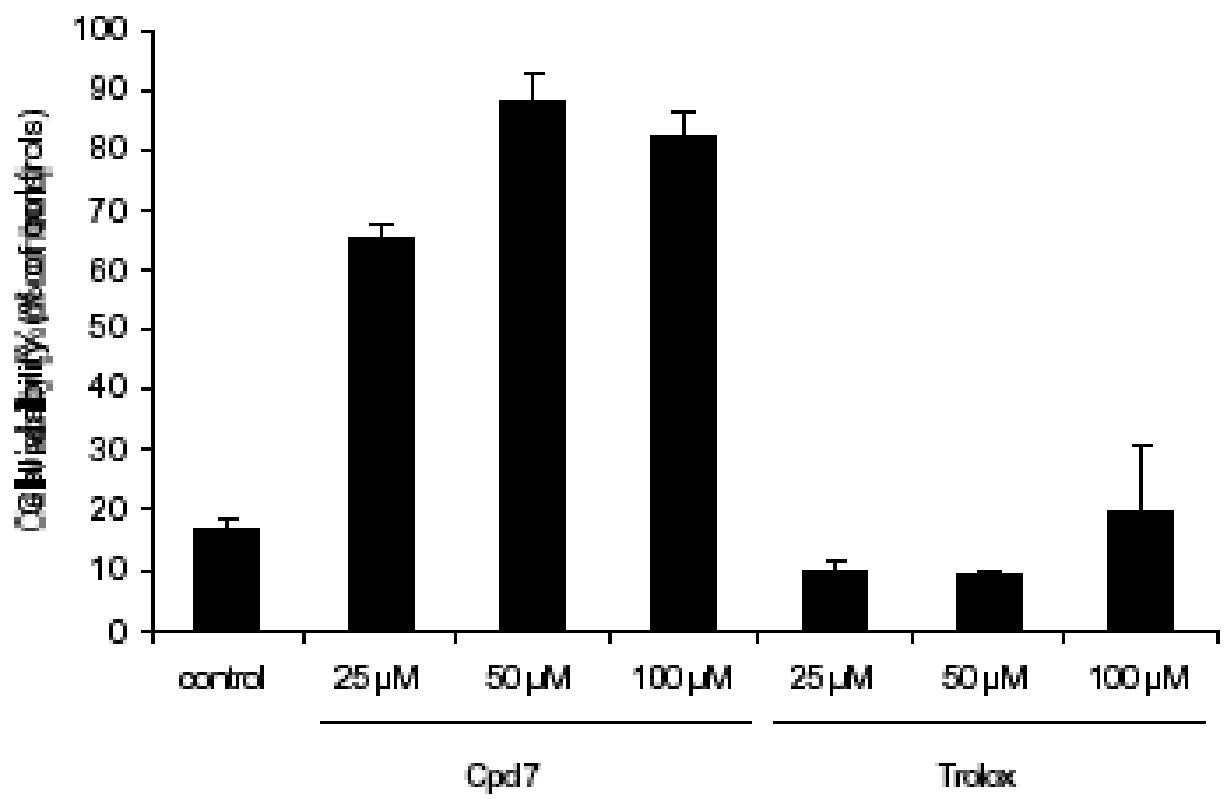

Graph 3. Protection of PC12 cells by cpd 7 and trolox against $\mathrm{H}_{2} \mathrm{O}_{2}$-induced oxidative stress. Cells were preincubated for 30 minutes with different concentrations of the antioxidant before addition of $125 \mu \mathrm{M}$ of $\mathrm{H}_{2} \mathrm{O}_{2}$ for additional 30 minutes. After that, cells were rinsed and fresh medium was added for 24 hours. Cell viability was then measured by the MTT test (mean \pm sem of 3 replicates). Control cells are cells treated with $\mathrm{H}_{2} \mathrm{O}_{2}$ only.

Table 8. Protection (\%) of PC12 Cells Against $\mathrm{H}_{2} \mathrm{O}_{2}$ Stress $(250 \mu \mathrm{M})$ by Tested Compounds $(50 \mu \mathrm{M})$.

\begin{tabular}{|c|c|}
\hline Cpd (1) & \% (2) \\
\hline \hline CLM & $17.44 \pm 9.72$ \\
\hline $\mathbf{1}$ & $0.06 \pm 6.96$ \\
\hline $\mathbf{3}$ & $9.63 \pm 8.23$ \\
\hline $\mathbf{1 1}$ & $15.73 \pm 2.32$ \\
\hline $\mathbf{2}$ & $47.50 \pm 16.71$ \\
\hline $\mathbf{6}$ & $58.07 \pm 15.71 *$ \\
\hline $\mathbf{7}$ & $59.56 \pm 14.62 *$ \\
\hline EGCG & $14.87 \pm 8.33$ \\
\hline DFO & $21.44 \pm 15.68$ \\
\hline deferiprone & $29.79 \pm 3.19$ \\
\hline
\end{tabular}

(1) see Table 1 for structures

(2) LDH assay; means ( \pm sem.) of triplicates; * $\mathrm{p}<0.05$

\subsection{LDL Protection Against Oxidation by Endothelial Cells}

We have previously demonstrated that aminopyrazines can efficiently protect LDLs against in vitro oxidation (see paragraph 5). Now, we analyse their capacity to inhibit LDL oxidation caused by endothelial cells (Eahy cells).

Cells were incubated with human LDLs $(100 \mu \mathrm{g} / \mathrm{ml})$ in the presence of a very small amount of $\mathrm{Cu}^{++}(1 \mu \mathrm{M})$, insufficient alone to oxidise LDLs but adequate to activate the oxidation of lipoproteins by cells; controls established that oxidation results really from cell action. Cellular oxidation of LDLs was evaluated after $24 \mathrm{~h}$ by using the
TBARS assay [55] (see paragraph 5). In a first series of experiments, aminopyrazines were tested at $0.625 \mu \mathrm{M}$ (Table 9). At this very low concentration, catechol derivatives $(2,6$, and 7) were highly efficient (almost total protection) while phenol derivatives $(1,3$, and 5$)$ revealed unable to prevent LDL oxidation. Therefore, we tested these compounds at higher concentrations (Table 10). Compound 1 was still inactive. This was most probably due to a bad incorporation into LDL particles. Indeed, the more lipophilic derivatives 3 and 5 showed a moderate activity at $5 \mu \mathrm{M}$. Survival of cells after $48 \mathrm{~h}$ has been analysed (by MTT assay) because oxidized LDLs are known to be toxic for endothelial cells (Table 10). A strong decrease of cell mortality was observed in the presence of aminopyrazine 3 at $5 \mu \mathrm{M}$. ${ }^{(d)}$

Table 9. LDL Oxidation by Endothelial Cells in the Presence of Aminopyrazines at $0.625 \mu \mathrm{M}$

\begin{tabular}{|c|c|}
\hline Treatment & TBARS (nmol/mg) ${ }^{(1)}$ prot LDL \\
\hline Cells + LDL & $5.75 \pm 0.47 * * *$ \\
\hline Cells + LDL + Cu & $61.69 \pm 4.63$ \\
\hline Cells + LDL + Cu + 1 & $60.26 \pm 5.54$ \\
\hline Idem +3 & $59.20 \pm 6.30$ \\
\hline Idem +5 & $53.83 \pm 7.60$ \\
\hline Idem +2 & $7.80 \pm 0.93 * * *$ \\
\hline Idem + 6 & $4.78 \pm 0.57 * * *$ \\
\hline Idem +7 & $9.61 \pm 2.26 * * *$ \\
\hline
\end{tabular}

(1) Means ( \pm sem.) of triplicates; ${ }^{* * *}, \mathrm{p}<0.001$ (comparison to cells $+\mathrm{LDL}+\mathrm{Cu}$ )

(d) Janssens, B.; Marchand, C.; Rees, J.-F., Unpublished results. 
Table 10. LDL Oxidation by Endothelial Cells and Cell Mortality in the Presence of Aminopyrazines at 1.25 to $5 \mu \mathrm{M}$

\begin{tabular}{|c|c|c|}
\hline Treatment & $\begin{array}{l}\text { TBARS (nmol/mg } \\
\operatorname{prot~LDL~}^{(1)}\end{array}$ & Mortality (2) (\%) \\
\hline Cells + LDL & $2.9 \pm 0.2 * * *$ & $5.63 \pm 1.08 * * *$ \\
\hline Cells + LDL + Cu & $47.5 \pm 3.2$ & $62.63 \pm 1.39$ \\
\hline+1 at $1.25 \mu \mathrm{M}$ & $47.9 \pm 2.7$ & $68.05 \pm 5.27$ \\
\hline+1 at $2.5 \mu \mathrm{M}$ & $46.7 \pm 1.2$ & $61.27 \pm 0.97$ \\
\hline+1 at $5 \mu \mathrm{M}$ & $45.6 \pm 1.7$ & $58.00 \pm 1.83$ \\
\hline+3 at $1.25 \mu \mathrm{M}$ & $38.1 \pm 1.5$ & $34.49 \pm 2.45 * * *$ \\
\hline+3 at $2.5 \mu \mathrm{M}$ & $26.6 \pm 2.8 * * *$ & $16.68 \pm 2.47 * * *$ \\
\hline+3 at $5 \mu \mathrm{M}$ & $15.1 \pm 1.2 * * *$ & $11.51 \pm 0.94 * * *$ \\
\hline+5 at $1.25 \mu \mathrm{M}$ & $44.0 \pm 1.9$ & $48.94 \pm 5.96$ \\
\hline+5 at $2.5 \mu \mathrm{M}$ & $34.4 \pm 1.4 * *$ & $22.24 \pm 3.19 * * *$ \\
\hline+5 at $5 \mu \mathrm{M}$ & $28.2 \pm 0.7 * * *$ & $20.03 \pm 0.90 * * *$ \\
\hline
\end{tabular}

(1), (2) Means ( \pm sem.) of triplicates $* *, p<0.01 ; * * *, p<0.001$ (comparisons to cells $+\mathrm{LDL}+\mathrm{Cu})$

The protective effect of aminopyrazines on endothelial cells exposed to oxidized LDLs has been independently controlled as follows: (i) LDLs were totally oxidized by $\mathrm{Cu}^{++}$then dialysed to eliminate all the metallic ions; (ii) cells were incubated for $24 \mathrm{~h}$ with oxidized, metal-free, LDLs (control: 100\% mortality); (iii) addition of tested compounds at $0.625 \mu \mathrm{M}$ protected against oxidized LDL toxicity (Table 11).

Table 11. Endothelial Cell Protection Against Oxidized LDL Toxicity

\begin{tabular}{|c|c|}
\hline Cpd & Mortality (\% control) \\
\hline \hline $\mathbf{1}$ & $73.52 \pm 8.44$ \\
\hline $\mathbf{3}$ & $17.73 \pm 1.76^{* * *}$ \\
\hline $\mathbf{5}$ & $19.83 \pm 6.76^{* * *}$ \\
\hline $\mathbf{6}$ & $10.79 \pm 1.82 * * *$ \\
\hline $\mathbf{7}$ & $4.20 \pm 2.32^{* * *}$ \\
\hline $\mathbf{9}$ & $11.91 \pm 4.96 * * *$ \\
\hline EGCG & $-0.67 \pm 0.15^{* * *}$ \\
\hline Catechol & $6.08 \pm 3.05 * * *$ \\
\hline Trolox & $14.29 \pm 6.59 * * *$ \\
\hline Vitamin E & $22.69 \pm 5.01 * * *$ \\
\hline Probucol & $75.92 \pm 4.13$ \\
\hline
\end{tabular}

The good activity of aminopyrazines 3, 5 (phenol derivatives), 2, 6 and 7 (catechol derivatives) was further confirmed. Moreover, diaminopyrazine 9, also considered in this assay, revealed to be the most active compound: 9 conferred a total protection and was more active than all the usual references.

\section{IN VIVO EVALUATION}

Till now, we have demonstrated the high reactivity of aminopyrazines with ROS/RNS, and established their ability to protect LDLs and DNA against damages due to radical species. In vitro tests further showed the high protective effect of aminopyrazines on cultured cells (keratinocytes, neuronal cells, endothelial cells) submitted to various oxidative stresses.

Since good bioavailability properties are also required for the development of new candidate drugs, we tested representative compounds in the "hamster cheek pouch" assay for in vivo protection against ischemia-reperfusion injury [66]. In this model, we could illustrate again the high therapeutic potential of aminopyrazines, but also, their good intestinal absorption and metabolic stability, as well as their ability to access to cellular compartments where ROS / RNS are produced or diffuse [67].

Fluorescent-labelled dextran was injected intravenously to animals and changes in the number of microvascular leaky sites were measured after local ischemia/reperfusion by direct observation on microscope of the cheek pouch. This allowed quantitative studies of microvascular permeability [66]. Animals were treated by gavage with the tested compounds at $30 \mathrm{mg} / \mathrm{kg}$ (or solvent), $30 \mathrm{~min}$ before anaesthesia. Results are given in percentages of inhibition of leaky sites, determined $30 \mathrm{~min}$ after the start of reperfusion. Table 12 shows that all compounds (except 1) provided good protection against the increase of microvascular permeability due to ischemia / reperfusion. The most active compounds ( 3 and 15) were still efficient at $3 \mathrm{mg} / \mathrm{kg}$ and as active as Apocynin, a commercially-available flavonoid usually considered as the reference in this test. ${ }^{\text {(e) }}$ Our compounds are thus orally bioavailable and seem to distribute well into the specific tissue where the efficiency is measured.

Table 12. Protective Effect of Aminopyrazines on Ischemia / Reperfusion Injury Leaks Inhibition (\%)

\begin{tabular}{|c|c|c|}
\hline $\operatorname{Cpd}^{(1)}$ & $30 \mathrm{mg} / \mathrm{kg}$ & $3 \mathrm{mg} / \mathrm{kg}$ \\
\hline 1 & 11 & n.d. \\
\hline 3 & 61 & 47 \\
\hline 4 & 49 & n.d. \\
\hline 13 & 35 & n.d. \\
\hline 7 & 57 & n.d. \\
\hline 15 & 68 & 51 \\
\hline Apocynin & n.d. & 59 \\
\hline
\end{tabular}

(1) see Table 1

n.d. $=$ not determined

(e) Verbeuren, T.; Rupin, A. ; Cordi, A.; Rees, J.-F. ; Marchand-Brynaert, J., Unpublished results. 
<smiles>Nc1ncc([AlH2])nc1[AlH2]</smiles><smiles>CC(=O)C=O</smiles>

Fig. (8).

\section{CONCLUSION}

The study of marine bioluminescence, and molecules responsible for this phenomenon, led us to discover the remarkable antioxidative properties of coelenteramine (CLM). Synthetic derivatives, structurally related to CLM, were also excellent antioxidants acting, most probably, via the formation of highly stabilized phenoxyl radicals, like the other (poly)phenolic antioxidants (e.g. EGCG). This first family of aminopyrazines was illustrated with the representative compounds $1,3,4,5,10,11,12$ and 13 (see Table 1).

Catechol derivatives 2, 6 and 7 (Table 1) constituted a second family of aminopyrazines not only possessing the antioxidant properties of the first family, but also endowed with metal chelating properties which enhanced and broadened the activity spectrum of these molecules. Compound 7 showed excellent therapeutic potential in all tests: LDL protection against oxidative damages, in vitro protection of mammalian cells (including DNA) submitted to an oxidative stress, and in vivo protection against injury due to ischemia/reperfusion. This aminopyrazine 7 can therefore be considered as a new "lead" in medicinal chemistry.

A third family of active compounds was formed by the diaminopyrazine derivatives $8,9,14$ and 15 (Table 1). In this case, the antioxidant capacity was not linked to the presence of a phenol (or catechol) motif. The mode of action of these compounds is not actually understood; they could act via mono-electronic transfers. Whatever it may be, in vitro activity of 9 (Table 11) and in vivo activity of 15 (Table 12) appeared very promising for the development of new "leads".

Aminopyrazines belonging to the two first families were chemical precursors of the corresponding imidazolopyrazinones by reaction with glyoxal derivatives [38] (Fig. (8)). These imidazolopyrazinones are also endowed with excellent antioxidative properties, independently of the presence or not of phenol (catechol) substituents $\left(\mathrm{R}^{1}, \mathrm{R}^{2}\right)$ [30]. However, this intrinsic property of the hetero-bicyclic system could be dramatically enhanced by the addition of such substituents on the pyrazine nucleus. In this case, oxidative degradation of the mother-compound (imidazolopyrazinone), on the location where the oxidative stress operates, will produce (at least, partially) an active daughter-compound (aminopyrazine with $\mathrm{R}^{1} / \mathrm{R}^{2}=$ phenol, catechol) susceptible to prolong in situ the antioxidant action. This could be illustrated by the higher activity of imidazolopyrazinones 16 and 17 comparatively to aminopyrazines 3 and 4 in the "hamster cheek pouch" assay (Table 13): compounds 16 and 17 are still efficient at 0.3 $\mathrm{mg} / \mathrm{kg}$ ! The therapeutic potential of imidazolopyrazinones and their related "cascade effect", i.e. the unmasking of a second-generation antioxidant during the oxidative metabolism of the first generation oxidant, is currently under investigation. This should provide a totally unprecedented mode of action.

Table 13. Protective Effect of Imidazolopyrazinones on Ischemia / Reperfusion Injury Leaks Inhibition (\%)

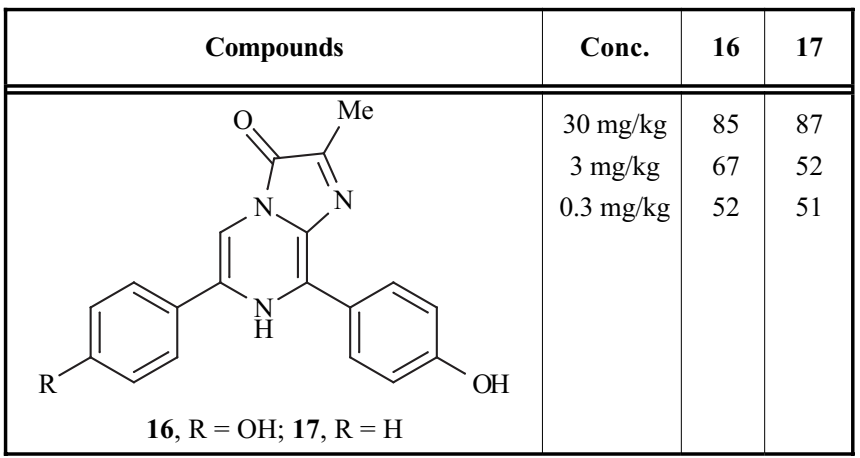

\section{ACKNOWLEDGEMENTS}

Part of this work has been supported by grants from the Direction Générale des Technologies et de la Recherche (DGTRE) of the Walloon Government, the Fonds de la Recherche Fondamentale Collective (FRFC), and Sopartec s.a., Belgium.
ABBREVIATIONS

AAPH $=\begin{aligned} & \text { 2,2'-azo-bis(2-amidinopropane) } \\ & \text { dihydrochloride }\end{aligned}$
$\mathrm{Ar}=$ Aryl substituent
CLD $=$ Coelenteramide
CLM $=$ Coelenteramine
CLZn $=$ Coelenterazine
CLZ-M -methyl-coelenterazine analog
CLZ-P $=$ Desferrioxamine
DFO Dihydrorhodamine-123
DHR $=$ Dimethoxyethane
DME $=$ Dimethylformamide
DMF $=$ Deoxyribonucleic acid
DMSO $=$




ECG $=$ Epicatechin gallate
EGCG $=$ Epigallocatechin gallate
HPLC $=$ High performance liquid chromatography
LDH $=$ Lactate dehydrogenase
LDL $=$ Malondialdehyde
MDA $=$ diphenyltetrazolium bromide
MTT $=$-bromosuccinimide
NBS $=$ Phosphate buffered saline
PBS $=$ Reactive nitrogen species
Rh
RNS

\section{REFERENCES}

[1] Sies, H., Ed. Oxidative Stress: Oxidants and Antioxidants, Academic Press: London, 1991.

[2] Rice-Evans, C. A.; Burdon, R. H., Eds. Free Radical Damage and its Control, New Comprehensive Biochemistry, vol. 28, Elsevier: Amsterdam, 1994.

[3] Halliwell, B.; Gutteridge, J. M. C., Eds. Free Radicals in Biology and Medicine, Oxford University Press: Oxford, 1999.

[4] Beckman, K. B.; Ames, B. N. Physiol. Rev. 1998, 78, 547.

[5] Morrissey, P. A.; O'Brien, N. M. Int. Dairy J. 1998, 8, 463.

[6] Krishna, M. C.; De Graff, W.; Hankovzsky, O. H.; Sar, C. P.; Kalai, T.; Jeko, J.; Russo, A.; Mitchell, J. B.; Hideg, K. J. Med. Chem. 1998, 41, 3477.

[7] Schackelfold, R. E.; Kaufmann, W. K.; Paules, R. S. Free Rad. And Biol. Med. 2000, 28, 1387.

[8] Kehrer, J. P. Toxicology 2000, 149, 43.

[9] Frei, B., Ed. Natural Antioxidants in Human Health and Disease, Academic Press: San Diego CA, 1994.

[10] Larson, R. A. Naturally Occurring Antioxidants, Lewis, CRC: Boca Raton FL, 1997.

[11] Packer, L.; Cadenas, E., Eds. Handbook of Synthetic Antioxidants, Marcel Dekker: New York, 1997.

[12] Gordon, M. H. Natural Product Reports 1996, 265.

[13] Andersson, C.-M.; Hallberg, A.; Hogberg, T. Adv. Drug. Res. 1996, $28,67$.

[14] Newman, D. J.; Cragg, G. M.; Snader, K. M. Nat. Prod. Rep. 2000, 17,215

[15] Branchini, B. R.; Murtiashow, M. H.; Magyar, R. A. J. Am. Chem Soc. 2002, 124, 2112.

[16] Sato, N.; Fukuya, S. J. Chem. Soc., Perkin Trans. 1 2000, 89.

[17] Rees, J.-F.; De Wergifosse, B.; Noiset, O.; Dubuisson, M.; Janssens, B.; Thompson, E. M. J. exp. Biol. 1998, 201, 1211.

[18] De Wergifosse, B.; Noiset, O.; Dubuisson, M.; MarchandBrynaert, J.; Baguet, F.; Rees, J.-F. In Bioluminescence and Chemiluminescence: Prospective for the 21st Century ; Roda, A.; Pazzagli, M.; Kricka, L. J.; Stanley, P. E., Eds; Wiley: Chichester, 1999, pp 396-399.

[19] Campbell, A. K.; Herring, P. J. Marine Biology, 1990, 104, 219

[20] Thompson, E. M.; Rees, J.-F. In Biochemistry and Molecular Biology of Fishes; Hochackka, P. W.; Mommsen, T. P., Eds; Elsevier: Amsterdam and New York, 1995, pp 435-466.

[21] Goto, T. Pure Appl. Chem. 1968, 17, 421.

[22] Usami, K.; Isobe, M. T. Tetrahedron 1996, 52, 12061.

[23] Nakano, M.; Sugioka, K.; Ushijima, Y.; Goto, T. Anal. Biochem. 1986, 159, 363
[24] Shimomura, O.; Wu, C.; Murai, A.; Nakamura, H. Anal. Biochem. 1998, 258, 230.

[25] Tampo, Y.; Tsukamoto, M.; Yonaha, M. Fed. Eur. Biochem. Soc. Lett. 1998, 430, 348.

[26] Gotoh, N.; Niki, E. Methods Enzymol. 1994, 233, 154.

[27] Ghislain, Y.; Rousselle, D.; Joannes, L.; Cornet, A.; Soumillion, J.P.; Marchand-Brynaert, J.; Brouillard, F.; Baguet, F.; Trouet, A.; Rees, J.-F. Archs Physiol. Biochem. 1995, 103, 1314.

[28] Devillers, I.; De Wergifosse, B.; Bruneau, M.-P.; Tinant, B.; Declercq, J.-P.; Touillaux, R.; Rees, J.-F.; Marchand-Brynaert, J. J. Chem. Soc., Perkin Trans. 2, 1999, 1481.

[29] Dubuisson, M. L. N.; De Wergifosse, B.; Trouet, A.; Baguet, F.; Marchand-Brynaert, J.; Rees, J.-F. Biochem. Pharmacol. 2000, 60, 471.

[30] Devillers, I.; Dive, G.; De Tollenaere, C.; Falmagne, B.; De Wergifosse, B.; Rees, J.-F.; Marchand-Brynaert, J. Bioorg. Med. Chem. Lett. 2001, 11, 2305.

[31] Dubuisson, M. L. N.; De Wergifosse, B.; Kremers, P.; MarchandBrynaert, J.; Trouet, A.; Rees, J.-F. Free Rad. Res. 2001, 34, 285.

[32] Janssens, B.; Marchand-Brynaert, J.; Rees, J.-F. Free Rad. Res. 2002, 36, 967 .

[33] De Wergifosse, B. Antioxidative properties of imidazolopyrazines and oxidation-derived aminopyrazines, and modulatory effect on DNA strand breakage. Ph.D. Thesis, Université catholique de Louvain, Louvain-la-Neuve (Belgium), 2000.

[34] Ohmiya, Y.; Hirano, T. Chem. Biol. 1996, 3, 337.

[35] Saito, R.; Hirano, T.; Niwa, H.; Ohashi, M. J. Chem. Soc., Perkin Trans 2 1997, 1711.

[36] Kuse, M.; Isobe, M. Tetrahedron, 2000, 56, 2629.

[37] Marchand-Brynaert, J.; De Tollenaere, C.; Cavalier, J.-F.; Burton, $\mathrm{M}$; Rees, J.-F. Aryl-substituted N,N-heterocyclic compounds, method for their preparation and their use in therapeutics and diagnostics. PCT / EP01 / 05588 (2001).

[38] Burton, M.; De Tollenaere, C.; Cavalier, J.-F.; Marchand, C.; Dussart, F.; Marchand-Brynaert, J.; Rees, J.-F. Free Rad. Res. 2003, 37, 145 .

[39] Kishi, Y.; Tanino, H.; Goto, T. Tetrahedron Lett. 1972, 13, 2747.

[40] Inoue, S.; Sugiura, S.; Kakoi, H. ; Hasizume, K. Chem. Lett. 1975, 141.

[41] Keeman, M. ; Jones, K. ; Hibbert, F. J. Chem. Soc., Chem. Commun, 1997, 323.

[42] Cavalier, J.-F.; Burton, M.; Dussart, F.; Marchand, C.; Rees, J.-F.; Marchand-Brynaert, J. Bioorg. Med. Chem. 2001, 9, 1037.

[43] Jeanjot, P.; Bruyneel, F.; Arrault, A.; Charbi, S.; Cavalier, J.-F.; Abels, A.; Marchand, C.; Touillaux, R.; Rees, J.-F.; MarchandBrynaert, J. Synthesis 2003, 513.

[44] Cavalier, J.-F.; Burton, M.; De Tollenaere, C. ; Dussart, F. ; Marchand, C. ; Rees, J.-F.; Marchand-Brynaert, J. Synthesis, 2001, 768.

[45] Migliavacca, E.; Carrupt, P.-A.; Testa, B. Helv. Chim. Acta 1997, 80, 1613.

[46] Migliavacca, E.; Ancerewicz, J.; Carrupt, P.-A.; Testa, B. Helv. Chim. Acta 1998, 81, 1337.

[47] Rajan, P.; Vedernikova, I.; Cos, P.; Vanden Berghe, D.; Augustyns, K.; Haemers, A. Bioorg. Med. Chem. Lett. 2001, 11, 215.

[48] Cheng, Z.; Ren, J.; Li, Y.; Chang, W.; Chen, Z. Bioorg. Med. Chem. 2002, 10, 4067.

[49] Dehareng, D.; Dive, G. J. Comput. Chem. 2000, 21, 483.

[50] Vancampenhout, N.; Dive, G.; Dehareng, D. Int. J. Quant. Chem. 1996, 60, 911.

[51] Dehareng, D.; Dive, G.; Géron, C. Recent Res. Devel. Chem. Physics 2002, 3, 193.

[52] Liegeois, C.; Lermusieau, G.; Collin, S. J. Agric. Food Chem. 2000, $48,1129$.

[53] Koppenol, W. H.; Kissner, R. ; Beckman, J. S. Methods Enzymol. 1996, 269, 296.

[54] Baraldo, L.M.; Forlano, P.; Parise, A.R.; Slep, L.D.; Olabe, J.A. Coord. Chem. Rev. 2001, 219-221, 881.

[55] Cotton, F.A. ; Wilkinson, G. ; Murillo, C.A. ; Bochmann, M., Eds. Advanced Inorganic Chemistry (Sixth Eidtion), John Wiley, New York, 1999, pp. 775-814.

[56] Child, M.D. ; Foulds, G.A. ; Percy, G.C. ; Thornton, D.A. J. Mol. Struct. 1981, 191.

[57] Bebbington, D.; Dawson, C. E.; Gaur, S.; Spencer, J. Bioorg. Med. Chem. Lett. 2002, 12, 3297.

[58] Chung, B.H., T. Wilkinson, J.C. Geer, Segrest, J.P. J. Lipid Res. $1980,21,284$ 
[59] Wey, H. E.; Pyron, L.; Woolery, M. Toxicol. Appl. Pharmacol. 1993, 120, 72 .

[60] Rubbo, H.; Trostchansky, A.; Botti, H.; Batthyany, C. Biol. Chem. 2002, 383 (3-4), 547-52.

[61] Gugliucci, A.; Menini, T. Life Sciences 2002, 71, 693.

[62] Denis, T.C.; Santosa, C.L.; Almeida, L.M. Free Rad. Res. 2002, 36 (5), 531.

[63] Collins, A.; Dobson, V. L. ; Dusinska, M. ; Kennedy, G. ; Stetina, R. Mutat. Res. 1997, 375, 183.
[64] Hinshaw, D.B.; Miller, M.T.; Omann, G.M.; Beals, T.F.; Hyslop, P.A. Brain Res. 1993, 615, 13.

[65] Vimard, F.; Nouvelot, A.; Duval, D. Biochem. Pharmacol. 1996, $51,1389$.

[66] Arrault, A.; Dubuisson, M.; Gharbi, S.; Marchand, C.; Verbeuren, T.; Rupin, A.; Cordi, A.; Bouskela, E.; Rees, J.-F.; MarchandBrynaert, J. Bioorg. Med. Chem. Lett. 2003, 13, 653

[67] Bouskela, E.; Cyrino, F.Z.; Lerond, L. British J. Pharmacol. 1997, 122, 1611 . 